\title{
Correlation between Students' Mathematical and Logical Spatial Intelligence in Terms of Understanding Concepts
}

\author{
M. Zaiyar ${ }^{1}$, Irfan Rusmar ${ }^{2}$, \& Trisna Yuniarti $^{2}$ \\ ${ }^{1}$ IAIN Zawiyah Cot Kala Langsa, Aceh, Indonesia \\ 2 Politeknik Teknologi Kimia Industri, Medan, Indonesia \\ *Corresponding author: m.zaiyar@iainlangsa.ac.id | Phone Number: +6285270329091
}

\section{ARTICLE HISTORY}

Received : 6 May 2020

Revised : 18 August 2020

Accepted : 22 September 2020

\section{KEYWORDS}

Spatial Intelligence; Mathematical Logical; Concept Understanding;

\begin{abstract}
This study aims to determine the relationship of junior high school students' spatial and mathematical logical intelligence based on understanding the concepts. Spatial intelligence indicators in this study are reviewed from students' abilities in using images as a tool for solving problems, connecting data with concepts that have been held, and finding patterns in solving problems. On the other hand, the indicators of students' mathematical logical intelligence is observed by looking at students' abilities to mention and understand information that is known in a problem, to draw up a plan of completion and to do mathematical calculations correctly. The indicators of understanding concepts are restating a concept, providing examples and non-examples of concepts, and applying concepts or algorithms in problem solving. The research method in this research is the Ex Post Facto correlational type, with using a purposive sampling as the sampling technique. The results of the data analysis obtained a correlation coefficient is around 0.93 with $86 \% \mathrm{R}$ square. The relationship between the spatial intelligence variables is shown by the understanding of concepts by $86 \%$, the level of the relationship, with the correlation coefficient is 0.93 , where mathematical logical intelligence with an understanding of $80 \%$, with the level of the relationship of 0.89 , and the relationship of spatial intelligence with a mathematical logical is described by a $77 \%$ level of the relationship, with $\mathbf{0 . 8 8}$, as the correlation coefficient. The results showed that there was a very strong relationship between spatial intelligence and logical mathematics in terms of understanding students' concepts.
\end{abstract}

\section{INTRODUCTION}

Mathematical ability is very important to improve students' achievement in learning, because the ability to do mathematics starts from students' variety of intelligence, where the diversity of the intelligence, by Howard Gardner was termed with "multiple intelligence". Howard Gardner argued that individuals have eight autonomous intelligences. Moreover, the individuals will apply this intelligence to create products and solve problems that are relevant to the society in which they live (Gardner, 1983, 1993, 1999, 2006b, 2006c). The eight intelligences that have been identified in-cluding: linguistic intelligence, logical-mathematical intelligence, spatial intelligence, musical intelligence, kinesthetic intelligence, naturalistic intelligence, interpersonal intelligence, and intrapersonal intelligence (Gardner, 1999).However, according to Gardner's analysis, only two intelligences are assessed and tested in schools, namely linguistic intelligence and logical-mathematical.

Every students' tends to have a different combination of in-telligence; however, we often only respect students based on their academic abilities, even though students have their own ways of showing their intelligence. Gardner (in Jayantika: 2013) stated that academic intelligence does not adequately cover one's apparent ability, in other words this is not able to inter- pret one's abilities fully. Intelligence is one of many important factors that can affect humans' achievement. So that, the success and failure of students is determined by the intelligence they have. Usually students who have low intelligence are difficult to be expected to achieve high achievement. However, there are also some students who have low intelligence, but can have good achievement in the learning process, hence, there is no guarantee that a student's high intelligence will automatically learn successfully in school.

Spatial intelligence is the intelligence that is related to images, creating images in the mind, enjoying charts, puzzles, and visualization tasks. Furthermore, spatial intelligence is the capacity of students to recognize an image, pattern, charts and be able to describe it in more concrete matters. On the other hand, the logical mathematical intelligence is defined as the ability of students to think logically and focus in solving mathematical problems, taking into consideration the correct order completion. Mathematical logical intelligence is also defined as a person's capacity to think logically in solving cases or problems and doing calculations mathematically.

Spatial intelligence and mathematical logical intelligence are very important in learning mathematics. According to the BSNP in the KTSP curriculum stated that the mathematics 
subjects need to be given to all students from elementary school level to advanced level, in order to provide students with the ability to think logically, analytically, systematically, critically, and creative, and the ability to work together, the competence to obtain, manage and use information to survive in ever-changing, uncertain and competitive conditions. In this case, the ability of students to understand a concept in the learning process really needs to be more directed in order to achieve the desired learning purposes. If students are not able to understand concepts in mathematics, students will be left behind, and so the students are also cannot be able to solve mathematical problems, problems in other disciplines and in their daily lives. In addition, to understanding the concepts, every student who will solve mathematical problems requires the existence of intelligence, and the intelligence that contributes to three dimension topics is the spatial and mathematical logical intelligence.

\section{RESEARCH METHODS}

This study is used Ex Post Facto method to analyze the data. The Ex Post Facto is a study conducted to examine events that have occurred and then look back to find out the factors that can cause these activities, and use the type of correlational not only to see the presence or absence of relationships, but also to see the scale of the relationship between the spatial and mathematical logical intelligence in terms of understanding students' concepts in the topic of 3 dimension, and sampling in this research is using the Purposive Sampling technique.

The data collected by using test and interview methods. The test consists of 6 essay questions and interviews are con-ducted with students about the questions that have been giv-en to students. Before the questions were given, the questions weremet the validation, reliable, level of difficulty, and distinguishing features coefficients. The hypothesis in this study tested by using multiple correlations and to calculate the size of the correlation using the coefficient of determination.

\section{RESULTS AND DISCUSSION}

\section{Results}

The data are the spatial and mathematical logical intelligence in terms of students' understanding about the concepts. The normality test in this study uses the Liliefors test because the sample is less than thirty. The summary of students' tests results regarding spatial intelligence, mathematical logic, and understanding of concepts is shown in the table 1 .

Table 1. Descriptive Statistics Students Ability

\begin{tabular}{lccccc}
\hline \multicolumn{1}{c}{ Variable } & $\mathrm{N}$ & Mean & $\begin{array}{c}\text { Standard } \\
\text { Deviasi }\end{array}$ & Min & Max \\
\hline Spatial Intelligence & 20 & 79,75 & 12,45 & 59 & 99 \\
\hline $\begin{array}{l}\text { Mathematical Logic } \\
\text { Intelligence }\end{array}$ & 20 & 79,45 & 11,50 & 60 & 100 \\
\hline Concepts Understanding & 20 & 83,10 & 13,19 & 60 & 100 \\
\hline
\end{tabular}

Based on the table 1 above, it can be seen that the average value of the spatial intelligence test is 79.75 , the average value of the logical intelligence test is 79.45 , and the average value of the concept understanding test is 83.10 . The average value of the three tests is included in the good category because it meets the standard score in SMP Negeri 2 Karang Baru, is 65. It means that the students have good spatial and logical intelligence and understand the concepts contained in the three dimension topic that they have learned. The summary of the calculation results of spatial intelligence data scores with students 'mathematical logical intelligence in terms of understanding students' concepts are presented in table 2 .

Table 2. The Data Calculation of the spatial intelligence, mathematical logical intelligence and understanding the concepts

\begin{tabular}{cccccccccc}
\hline $\mathbf{N}$ & $\sum \mathbf{X}_{1}$ & $\sum \mathbf{X}_{2}$ & $\sum \mathbf{Y}$ & $\sum \mathbf{X}_{1}{ }^{2}$ & $\sum \mathbf{X}_{2}{ }^{2}$ & $\sum \mathbf{Y}^{2}$ & $\sum \mathbf{X}_{1} \mathbf{X}_{2}$ & $\sum \mathbf{X}_{1} \mathbf{Y}$ & $\sum \mathbf{X}_{2} \mathbf{Y}$ \\
\hline \multirow{2}{*}{20} & 159 & 158 & 166 & 130 & 128 & 141 & 129 & 135 & 134 \\
& 5 & 9 & 2 & 147 & 761 & 416 & 121 & 469 & 640 \\
\hline
\end{tabular}

Table 2 above explains that from 22 students, the total value of spatial intelligence $(\mathrm{X} 1)=1595$, the number of mathematical logical intelligence values $(\mathrm{X} 2)=1589$, and the total value of understanding students' mathematical concepts $(\mathrm{Y})=1662$. Then the number of $\mathrm{X} 1$ squares $=130147, \mathrm{X} 2$ squared $=$ $128761, Y$ squared $=141416$. And the number of spatial intelligence variables (X1) times the number of mathematical logical intelligence variables $(\mathrm{X} 2)=129121$, the number of spatial intelligence variables (X1) times the number of concepts of understanding $(\mathrm{Y})=135469$, and the number of mathematical logical intelligence variables (X2) multiplied by the number of understanding concepts $(\mathrm{Y})=134640$. From these data, the correlation value between the spatial intelligence variables (X1) and conceptual understanding $(\mathrm{Y})$ is $\mathrm{r}_{-}\left(\mathrm{yx} \_1\right)=$ 0.93 with a positive correlation value and the level of relationship is very strong, the correlation obtained between mathematical logical intelligence variables (X2) with the understanding of the concept $(\mathrm{Y})$ is $\mathrm{r}_{-}\left(\mathrm{yx} \_2\right)=0.89$ with a positive correlation value and the level of relationship is very strong, the correlation value obtained between the spatial intelligence variable (X1) with the logical intelligence variable (X2) is $r_{-}\left(x_{-} 1 x_{-} 2\right)=0.88$ with a positive correlation value and the level of a very strong relationship, and the correlation obtained between the spatial intelligence variable (X1) and the logical intelligence variable (X2) in terms of understanding the concept $(\mathrm{Y})$ is $\llbracket \mathrm{R} \_\mathrm{y} \rrbracket \_\left(\mathrm{x} \_1 \quad \mathrm{x} \_2\right)=0.93$ with a positive correlation value and a very strong relationship level. It can be seen in the table 3 .

Table 3. The Correlation Results

\begin{tabular}{cccccc}
\hline $\mathrm{yx}_{\mathrm{yx}_{1}}$ & $\mathrm{r}_{\mathrm{yx}_{2}}$ & $\mathrm{r}_{\mathrm{x}_{1} \mathrm{x}_{2}}$ & $\mathrm{R}_{\mathrm{y}_{\mathrm{x}_{1} \mathrm{x}_{2}}}$ & \multicolumn{2}{c}{ Level of Correlation } \\
\hline 0,93 & 0,89 & 0,88 & 0,93 & $0,80-1,000$ & Very Strong \\
\hline
\end{tabular}

After obtaining the multiple correlation coefficients, significance test will be tested by using the F test which can be seen in the table 4.

Table 4. The Results of Significance Test

\begin{tabular}{cccc}
\hline No. & & Significance Test & Values \\
\hline 1 & $F_{\text {count }}$ & 43,00 \\
\hline 2 & $F_{\text {table }}$ & 3,59 \\
\hline
\end{tabular}

Based on table 2, it can be explained that the $\mathrm{F}$ count value is 43.00 and the $F$ table from $a=0.05$ with the degree of freedom nominator $\mathrm{df}=\mathrm{k}=2$ and the denominator $\mathrm{dk}=(\mathrm{n}-\mathrm{k}$ $1)=(20-2-1)=17$ so we get $\mathrm{F}$ table $=3.59$. The details can be perceived in the distribution table of $F$ values. Based on the explanation above, it can be inferred that the value of $\mathrm{F}$ count is greater than $\mathrm{F}$ table ( $\mathrm{F}$ count $>\mathrm{F}$ table) or $43>3.59$, then $\mathrm{Ha}$ is accepted, it means than there is a significant relationship between spatial intelligence and mathematical logical intelligence in terms of understanding students' concepts. 
Furthermore, it can be said that when students solve problems, especially in the matter of space construction, they use spatial intelligence and mathematical logical intelligence in terms of understanding their concepts. Whereas, the level of the correlation between variables can be seen from the coefficient of determination in the table 5 .

Table 5. Correlation Coefficients

\begin{tabular}{|c|c|}
\hline Correlation & $\mathbf{R}_{\mathbf{2}}$ \\
\hline $\mathrm{r}_{-}\left(\mathrm{yx} \_1\right)$ & $86 \%$ \\
\hline $\mathrm{r}_{-}\left(\mathrm{yx} \_2\right)$ & $80 \%$ \\
\hline$r_{-}\left(x_{-} 1 x_{-} 2\right)$ & $77 \%$ \\
\hline$\llbracket R \_y \Omega_{-}\left(x_{-} 1 x_{-} 2\right)$ & $86 \%$ \\
\hline
\end{tabular}

Based on the table above, it explains that the level of the correlation between spatial intelligence and students' understanding of the concept $\left(\mathrm{r}_{-}\left(\mathrm{yx}_{-} 1\right)\right)$ is $86 \%$ with the remaining $14 \%$ is determined by other variables not predicted by researchers such as other intelligences in multiple intelligence, the level of the correlation between mathematical logical intelligence and the understanding of student concepts ( $\mathrm{r}_{-}\left(\mathrm{yx} \_2\right)$ ) is $80 \%$ with the remaining $20 \%$ determined by other variables that are not predicted by researchers such as other intelligences in multiple intelligence, the level of the correlation between spatial intelligence and mathematical logical intelligence $\left(r_{-}\left(x_{-} 1 x_{-} 2\right)\right)$ is $77 \%$ with the remaining $23 \%$ is determined by other variables not predicted by researchers such as other intelligences in multiple intelligence, and the level of the correlation between spatial intelligence and mathematical logical intelligence in terms of understanding students' concepts ( $\left[\mathrm{R} \_\mathrm{y} \rrbracket \_\left(\mathrm{x}_{-} 1 \mathrm{x} \_2\right)\right)$ is $86 \%$. Therefore, it can be concluded that the relationship of X1 with X2 in terms of $\mathrm{Y}$ by $86 \%$ and the remaining $14 \%$ is determined by other variables that are not predicted by researchers like other intelligences in multiple intelligence.

\section{CONCLUSION}

Based on the study's results, it can be concluded that there is a significant relationship between spatial intelligence and mathematical logical intelligence of students in terms of students' understanding of the concept of three dimensions in SMP Negeri 2 Karang Baru. This is indicated by the results of the analysis on hypothesis testing that the value of the multiple correlation coefficient has a very strong level of correlation with values approaching $+1,0.93$ by obtaining a significance $F$ count $>$ $\mathrm{F}$ table $(43>3.59)$, then $\mathrm{Ha}$ is accepted. The relationship between other variables also has a very strong level of relationship, namely the relationship between spatial intelligence with students 'understanding of concepts has a relationship level of $0.93(0.80-1.00$ is very strong), the relationship between mathematical logical intelligence with students' understanding of concepts gained the relationship of $0.89(0.80-1.00$ is very strong), and the relationship of spatial intelligence with mathematical logical intelligence reaches a relationship level of 0.88 (0.80-1.00 is very strong).

\section{REFERENCES}

Amir, A. (2013). Pembelajaran matematika dengan menggunakan kecerdasan majemuk (multiple intelligences). Logaritma: Jurnal Ilmu-ilmu Pendidikan dan Sains, 1(01).

Ansori, M. (2016). Pengaruh Kecerdasan Verbal-Linguistik Dan Kecerdasan Visuo-Spatial Terhadap Kreatifitas
Siswa Islamic Boarding School SMP Islam Al-A'la Tahun Ajaran 2015/2016. Jurnal Al Lubab, 1(1).

Nurrahmah, A. (2015). Pengaruh Kecerdasan Logik Matematika dan Minat Belajar terhadap Prestasi Belajar Matematika. Formatif: Jurnal Ilmiah Pendidikan MIPA, $5(2)$.

Arikunto, Suharsimi. (2008). Dasar-Dasar Evaluasi Pendidikan Edisi Revisi. Jakarta : PT. Bumi Aksara.

Depdiknas. (2001). Kamus Besar Bahasa Indonesia.(Jakarta : Balai Pustaka, 2001).

Eveline Siregar dan Hartini Nara. (2011). Teori Belajar dan Pembelajaran. Bogor: Ghalia Indonesia

Fadilah, Elis Nur dan Dian Septi Nurafifah. (2014). Kecerdasan Visual-Spasial siswa SMP dalam Memahami Bangun Ruang Ditinjau Dari Perbedaan Kemampuan Matematika. Jurnal Pendidikan Matematika STKIP PGRI Sidoarjo. 2(2).

Zulfairanatama, G., \& Hadi, S. (2013). Kecerdasan logika-matematika berdasarkan multiple intelligences terhadap kemampuan matematika siswa SMP di Banjarmasin. EDU-MAT: Jurnal Pendidikan Matematika, $1(1)$.

Hamdani, D., Kurniati, E., \& Sakti, I. (2012). Pengaruh model pembelajaran generatif dengan menggunakan alat peraga terhadap pemahaman konsep cahaya kelas VIII di SMP Negeri 7 Kota Bengkulu. Exacta, 10(1), 79-88.

Hasanah, W. (2013). Kecerdasan Logis-Matematis Siswa dalam Memecahkan Masalah Matematika pada Materi Komposisi Fungsi. MATHEdunesa, 2(2).

Jayantika, I. G. A. N. T., Ardana, I. M., \& Sudiarta, P. I. G. P. (2013). Kontribusi bakat numerik, kecerdasan spasial, dan kecerdasan logis matematis terhadap prestasi belajar matematika siswa SD Negeri di Kabupaten Buleleng. Jurnal Pendidikan dan Pembelajaran Matematika Indonesia, 2(2).

Kesumawati, Nila. (2008). Pemahaman Konsep Matematik dalam Pembelajaran Matematika. Palembang: Semnas Matematika dan Pendidikan Matematika.

Khoiri, M. (2014, November). Pemahaman siswa pada konsep segiempat berdasarkan teori van Hiele. In Prosiding Seminar Nasional Matematika, Universitas Jember (Vol. 19).

Kuncara, A. W., Sujadi, I., \& Riyadi, R. (2015). Analisis Proses Pembelajaran Matematika Berdasarkan Kurikulum 2013 pada Materi Pokok Peluang Kelas X SMA Negeri 1 Surakarta. Jurnal Pembelajaran Matematika, 4(3).

Liana, L. (2009). Penggunaan MRA dengan SPSS untuk menguji pengaruh variabel moderating terhadap hubungan antara variabel independen dan variabel dependen. Dinamik, 14(2).

Librianti, V. D., \& Sugiarti, T. (2015). Kecerdasan Visual Spasial dan Logis Matematis dalam Menyelesaikan Masalah Geometri Siswa Kelas VIII A SMP Negeri 10 Jember (Visual Spatial and Logical Mathematical Intelligence in Solving Geometry Problems Class VIII A SMP Negeri 10 Jember). Artik. Ilm. Mhs, 1(1), 1-7.

Afrilianto, M. (2014). Pendekatan Metaphorical Thinking Untuk Meningkatkan Kemampuan Kompetensi Strategis Matematis Siswa SMP. In Prosiding Seminar Nasional Matematika Dan Pendidikan Matematika (Vol. 68).

Murizal, A. (2012). Pemahaman konsep matematis dan model pembelajaran quantum teaching. Jurnal pendidikan matematika, 1(1).

Musa, L. A. D. (2016). Level Berpikir Geometri Menurut Teori Van Hiele Berdasarkan Kemampuan Geometri dan 
Perbedaan Gender Siswa Kelas VII SMPN 8 Pare-Pare. Al-Khwarizmi: Jurnal Pendidikan Matematika dan Ilmu Pengetahuan ALam, 4(2), 103-116.

Ningsih, Y. L. (2016). Kemampuan pemahaman konsep matematika mahasiswa melalui penerapan lembar aktivitas mahasiswa (LAM) berbasis teori APOS pada materi turunan. Edumatica: Jurnal Pendidikan Matematika, 6(01).

Noveradila, S., \& Larasati, D. (2015). Alat Permainan Edukatif Untuk Meningkatkan Kecerdasan Logika-Matematika Anak Usia Dini. Product Design, 2(1), 162144.

Novitasari, D., \& Abdul Rahman, A. (2015). Profil Kreativitas Siswa dalam Pemecahan Masalah Matematika ditinjau dari Kecerdasan Visual Spasial dan Logis Matematis pada Siswa SMAN 3 Makasar. Daya Matematis: Jurnal Inovasi Pendidikan Matematika, 3(1), 41-50.

Nugroho, Zhuhda Basofi dkk. (2016). Eksperimentasi Model Pembelajaran Think Talk Write (TTW) dan Model Pembelajaran Think Pair Share (TPS) dengan Pendekatan Saintifik Pada Materi Bilangan Ditinjau dari Kecerdasan Logis Matematis Siswa Kelas VII Smp Negeri Se-Kabupaten Blora Tahun Pelajaran 2014/2015. Jurnal Elektronik Pembelajaran Matematika, 4(2).

Purwanto, Budi. (2010). Geometri dan Teori Van Hiele. Jurnal Pendidikan Matematika, 5(9).

Raharjo, Hendrik. (2014). Pembelajaran Berbasis Masalah untuk Membangun Kemampuan Pemahaman, Komunikasi dan Disposisi Matematik. Prosiding Seminar Nasional Pendidikan Matematika ProgramPasca Sarjana STKIP Siliwangi Bandung. Volume 1, ISSN 2355-0473.

Riduwan. (2007). Belajar Mudah penelitian untuk guru, karyawan danpeneliti pemula. Bandung: Alfabeta.

Rumengan, Jemmy. (2009). Metodologi Penelitian dengan Menggunakan SPSS. Bandung : Citapustaka Media Perintis.

Sahdiana. (2013). Keterampilan Guru Memberikan Penguatan (Reinforcement) Dan Pengaruhnya Terhadap Kreatifitas Belajar Matematika Siswa SMP Negeri 5 Langsa.Skripsi. Langsa : IAIN Zawiyah Cot Kala Langsa.

Sari, Deka Purnama dkk. (2016). Meningkatkan Kemampuan Pemahaman Matematis Melalui Pendekatan Pembelajaran Student Teams Achivement Division. Jurnal Riset Pendidikan Matematika. 3(1)

Sofyana, Aisia dkk. (20013). Profil Keterampilan Geometri Siswa SMP dalam Memecahkan Masalah Geometri Berdasarkan Level Perkembangan Van Hiele. Surabaya: 1(4).

Sudana, I Nyoman. (2015). Pengaruh Model Pembelajaran Konflik Kognitif Terhadap Pemahaman Konsep Sains Ditinjau Dari Gaya Kognitif Siswa SMP Negeri 3 Semarapura, Semarang : Jurnal Ilmiah Pendidikan (JIP) PGRI Klungkung, 1(1).

Sudiyono, Anas. (2008). Pengantar Statistik Pendidikan. Jakarta : PT Raja Grafindo Prenada.

Sugiyarti. (2013). Pengembangan Buku Siswa dengan Mengacu Lima Fase Belajar Model Van Hiele pada Materi Bangun Ruang Sisi Datar Kelas VIII SMP Laboratorium Universitas Negeri Malang. Jurnal Pendidikan Sains, 1(1).

Sugiyono. (2010). Metode Penelitian Pendidikan. Bandung: Alfabeta.

Suhendri, H. (2011). Pengaruh kecerdasan matematis-logis dan kemandirian belajar terhadap hasil belajar matematika. Formatif: Jurnal Ilmiah Pendidikan MIPA, 1(1).
Suliastyarini, Margareta Maya dan F Gatot Iman Santoso. (2015). Pengaruh Kecerdasan Visual-Spasial Terhadap Hasil Belajar Matematika dalam Problem Based Learning Pada Siswa SMA Kelas X. Jurnal Ilmiah Edukasi Matematika (JIEM). 1(1).

Sumarmo, (2013). Penerapan Metode Penemuan Terbimbing Untuk Pemahaman Siswa Kelas VII SMPN 6 Palu Pada Materi Hubungan Sudut-Dalam dan Sudut Luar-Segitiga. Jurnal Elktronik Pendidikan Matematika Tadulako, 1(1)

Supardi dan Darwyan Syah. (2009). Pengantar statistik pendidikan. Jakarta: Diadit Media.

Syahrum dan Salim. (2007). Metodologi Penelitian Kuantitatif. (Bandung : Citapustaka Media.

Wahoyo, Tri Kusdarmanto dan Mega Teguh Budiarto. (2014). Kecerdasan visual-spasial siswa SMP dalam Menyelesaikan Masalah Geometri Ruang Ditinjau Dari Perbedaan Kemampuan Matematika. Mathedunesa Jurnal Ilmiah Pendidikan Matematika. 3(1)

Wardhani, Dian dkk. (2016). Origami Terhadap Kecerdasan Spasial Matematika Siswa. Jurnal Pendidikan. 1(5)

Zhuhda Basofi Nugroho, dkk. (2016). Eksperimentasi Model Pembelajaran Think Talk Write (TTW) dan Model Pembelajaran Think Pair Share (TPS) dengan Pendekatan Saintifik Pada Materi Bilangan Ditinjau dari Kecerdasan Logis Matematis Siswa Kelas VII SMP Negeri Se-Kabupaten Blora Tahun Pelajaran 2014/2015. Jurnal Elektronik Pembelajaran Matematika, 4(2).

Zulfairatama, Gilang dan Sutarto Hadi. (2013). Kecerdasan Logika Matematika Berdasarkan Multiple Intellinces Terhadap Kemampuan Matematika Siswa SMP di Banjarmasin. EDU-MAT Jurnal Pendidikan Matematika, $1(1)$. 